\title{
Upaya Pencegahan Perceraian Akibat Media Sosial dalam Perspektif
} Sosiologis

\author{
Aulia Nursyifa ${ }^{1}$, Eti Hayati \\ Universitas Pamulang \\ ${ }^{1}$ Email: aulianursyifa@unpam.ac.id
}

\begin{abstract}
Abstrak
Kemajuan teknologi bukan hanya berdampak positif bagi kehidupan manusia, tetapi penyalahgunaan teknologi dapat menimbulkan masalah sosial. Salah satu akibat penyalahgunaan teknologi menimbulkan fenomena maraknya perceraian akibat adanya perselingkuhan antara suami dan isteri yang dapat terekam lewat media sosial. Tujuan dari penelitian ini berupaya untuk mengetahui upaya yang dilakukan dalam mencegah perceraian akibat penyalahgunaan media sosial dalam perspektif Sosiologis. Penelitian ini menggunakan metode penelitian kualitatif dengan pendekatan fenomenologi, pengolahan data menggunakan Nvivo 12. Hasil penelitian menunjukkan bahwa perceraian akibat penyalahgunaan media sosial dipicu karena adanya perselingkuhan antara suami isteri lewat media sosial sehingga membuat pertengkaran yang terjadi terus menerus. Upaya pencegahan perceraian akibat penyalahgunaan media sosial dilakukan oleh berbagai pihak diantaranya upaya dari pasangan agar tidak bercerai, pihak keluarga yang berupaya mendamaikan, pihak pengadilan yang berupaya melakukan mediasi, bahkan pemerintah kota yang giat memberikan sosialisasi tentang aturan ketahanan keluarga, program pendidikan pra nikah, program sekolah ayah bunda, dan berupaya memperkuat fungsi keluarga. Upaya pencegahan perceraian akibat penyalahgunaan media sosial dapat berjalan efektif didukung dengan adanya kerjasama antar institusi beserta semua elemen masyarakat untuk memperkuat ketahanan keluarga.
\end{abstract}

Kata kunci : pencegahan, perceraian, media sosial

\section{Efforts To Prevent Divorce From Social Media in a Sociological Perspective}

\begin{abstract}
Technological advances not only have a positive impact on people's lives, but misuse of technology can cause social problems. One of the consequences of technology misuse is the phenomenon of divorce due to an affair between husband and wife that can be recorded through social media. The purpose of this study seeks to know the efforts made in preventing divorce due to social media abuse in a Sociological perspective. This research uses qualitative research methods with phenomenological approach, data processing using Nvivo 12. The results showed that divorce due to social media abuse was triggered by an affair between the husband and wife through social media resulting in an ongoing altercation. Efforts to prevent divorce due to social media abuse are carried out by various parties such as efforts from couples not to divorce, families who seek to reconcile, courts that seek mediation, even the city government that actively provides socialization about family resilience rules, premarital education programs, mother's father's school program, and efforts to strengthen the functioning of the family. Efforts to prevent divorce due to social media abuse can be effectively supported by cooperation between institutions and all elements of society to strengthen family resilience.
\end{abstract}

Keywords : prevention, divorce, social media 


\section{PENDAHULUAN}

Penggunaan teknologi di era revolusi industri 4.0 membuat berbagai perubahan dalam kehidupan masyarakat. Pada era disrupsi ini ditandai dengan adanya perkembangan pesat dibidang teknologi internet (Schwab, 2016). Teknologi memberikan kemudahan bagi manusia untuk saling terhubung satu sama lain lewat media sosial. Pada tahun 2019 pengguna media sosial yang aktif di Indonesia terdapat 150 juta pengguna (Hootsuite, 2019). Platform media sosial yang saat ini sering digunakan oleh masyarakat seperti WhatsApp, Facebook, Twitter, Instagram, Facebook Messenger, dan sebagainya.

Keberadaan media sosial dapat menimbulkan terjadi perubahan sosial dalam kehidupan masyarakat yang dapat mengarahkan masyarakat untuk melakukan perilaku positif maupun negatif (Cahyono, 2010). Media sosial dapat meniadakan status sosial seseorang karena lewat media sosial siapapun dapat menjalin komunikasi tanpa memandang status yang dimilikinya tidak mengenal status sosial termasuk status pernikahan (Watie, 2011). Media sosial dapat berdampak positif maupun negatif tergantung pada penggunanya, jika menggunakan media sosial dilakukan secara negatif maka akan menimbulkan permasalahan sosial dalam kehidupan masyarakat. Salah satu permasalahan yang akibat penyalahgunaan media sosial menimbulkan masalah perceraian.

Berdasarkan Undang-Undang Republik Indonesia Nomor 1 Tahun 1974 Pasal 38 tentang Perkawinan, maka perkawinan dapat dapat diputuskan karena adanya kematian salah satu pihak, perceraian atas tuntutan suami maupun isteri, dan atas adanya putusan dari pengadilan (Ramulyo, 2014). Perceraian dikatakan sah jika ada keputusan dari pengadilan, setelah pengadilan berusaha untuk mendamaikan kedua belah pihak.

Data yang dikutip dari website Mahkamah Agung Republik Indonesia, sepanjang tahun 2019 terdapat 604.997 kasus pengajuan perceraian (mahkamahagung.go.id, 2019). Angka tersebut bisa saja dan terus meningkat jika terus dibiarkan, sehingga perlu adanya upaya yang dilakukan menekan perceraian di Indonesia. Perceraian yang terjadi di Indonesia disebabkan oleh berbagai faktor penyebabnya meliputi: terjadinya perselisihan yang terjadi terus menerus, masalah ekonomi, ada salah satu pihak yang meninggalkan, terjadinya kekerasan dalam rumah tangga, dan faktor penyebab lainnya.

Salah satu penyebab perceraian yang menjadi fokus kajian dalam penelitian ini yaitu terkait dengan penyebab perceraian akibat adanya perselisihan secara terus-menerus yang dilakukan antara pasangan suami istri. Penyebab terjadinya pertengkaran akan ditelusuri lebih mendalam dalam sidang perceraian di Pengadilan Agama sehingga dapat membuktikan bahwa perceraian yang terjadi akibat adanya perselingkuhan yang dapat terekam di media sosial.

Sejak dahulu perselingkuhan sudah menjadi pemicu perpisahan dalam rumah tangga, namun sejak adanya teknologi yang digunakan semua kalangan termasuk suami istri, sehingga mudah untuk merekam jejak perselingkuhan yang dilakukan pasangan yang diungkap lewat media sosial.

Pada dasarnya penggunaan media sosial yang digunakan secara negatif dapat memicu perselingkuhan dalam rumah tangga. Hal ini bisa terjadi karena banyak faktor diantaranya: kebebasan dalam penggunaan media sosial tanpa memandang status yang dimiliki; kejenuhan terhadap pasangan; ketidakpuasan terhadap pasangan dengan selalu membandingkan kekurangan pasangan dengan selingkuhan yang dikenal di media sosial; ketidaksetiaan terhadap pasangan; keinginan untuk menikah kembali; keinginan untuk kembali dengan mantan pacar yang ditemui di media sosial; dan sebagainya.

Pasangan suami isteri menggunakan media sosial seperti Facebook dan WhatsApp dengan intensitas penggunaan yang cukup tinggi akan beresiko memicu adanya perselingkuhan antara pasangan suami istri. Awalnya sekedar interaksi dalam dunia maya dengan lawan jenis, saling chating secara intensif, saling curhat, 
saling perhatian, sehingga timbul perasaan sayang. Akhirnya bertemu dalam dunia nyata dan menjalin hubungan terlarang. Ketika perbuatan perselingkuhan tersebut terungkap oleh pasangan sehingga dapat menimbulkan pertengkaran yang terjadi secara terus menerus, dan pada akhirnya pernikahan berakhir dengan perceraian.

Dalam perspektif sosiologis keluarga sebagai salah satu lembaga sosial yang rentan terjadinya konflik, keluarga dapat melahirkan disintegrasi dimana anggota keluarga yang berinteraksi saling bermusuhan yang dapat memicu sebuah konflik. Menurut Simmel (Cahyono, 2010) penyebab terjadinya konflik karena adanya: kecemburuan, kebencian, keinginan, dan nafsu yang membuat seseorang berkonflik dengan orang lain, termasuk dengan pasangannya. Konflik yang terjadi dalam kehidupan rumah tangga secara terus menerus itulah yang membuat pasangan memilih untuk memutuskan pernikahannya. Oleh karena itu, penggunaan media sosial yang disalahgunakan dapat menjadi malapetaka yang dapat melahirkan konflik di dalam keluarga. Perlu adanya upaya yang dapat dilakukan untuk mengatasi masalah tersebut.

Penelitian terkait dengan perceraian akibat media sosial telah dilakukan oleh para peneliti terdahulu. Media sosial menjadi penyebab permasalahan keluarga yang berdampak pada perceraian rumah tangga berdasarkan kajian Hukum Islam (Asmaret, 2018; Hajar, 2019; Harlina, 2015; Ulfa, 2019). Keberadaan jejaringan sosial berakibat terhadap tingginya tingkat perceraian (Noor, Djaba, \& Enomoto, 2016). Keberadaan media sosial seperti Facebook berkorelasi terhadap tingginya angka perceraian dan ketidakpuasan terhadap pernikahan (Valenzuela, Halpern, \& Katz, 2014); Facebook memberikan pemicu perselingkuhan yang berakibat pada peningkatan kasus perceraian dalam kajian putusan Pengadilan Agama (Astuti, 2012; Baso, 2012; Safria, 2014). Berdasarkan kajian dari berbagai penelitian terdahulu yang menunjukkan bahwa perceraian akibat adanya penggunaan media sosial yang tidak bijak, namun dari berbagai penelitian tersebut belum adanya pembahasan khusus mengenai upaya pencegahan perceraian akibat media sosial dalam kajian Sosiologis.

Fenomena kasus perceraian akibat penyalahgunaan media sosial telah terjadi di berbagai daerah di Indonesia, salah satunya terjadi di kota Depok. Sepanjang bulan Juli 2019 terdapat 2532 kasus perceraian yang dipicu akibat tidak bijak menggunakan media sosial (Viva.co.id, 2019). Berdasarkan data Pengadilan Agama Depok (2019) jumlah perceraian di kota Depok pada tahun 2019 mencapai 4923 kasus. Angka tersebut cukup tinggi sehingga dikhawatirkan jika terus dibiarkan jumlahnya dari tahun ke tahun akan mengalami kenaikan.

Upaya yang dilakukan dalam menekan angka perceraian telah dilakukan pemerintah daerah lewat lembaga-lembaga khusus, salah satunya lewat program ketahanan keluarga. Meskipun pada kenyataannya upaya menurunkan angka perceraian sampai dengan saat ini masih dalam proses belum terlihat signifikan dampaknya. Oleh karena itu, perlu adanya upaya yang dilakukan oleh berbagai pihak agar dapat dirasakan langsung manfaatnya oleh masyarakat untuk menekan angka perceraian di kota Depok. Berdasarkan permasalahan tersebut mendorong peneliti untuk mengungkap permasalahan perceraian akibat media sosial yang marak terjadi di kota Depok. Artikel ini bertujuan untuk mengetahui upaya yang dilakukan berbagai pihak dalam mencegah perceraian akibat penyalahgunaan media sosial dalam perspektif Sosologis. Pentingnya masalah ini untuk diteliti agar dapat menjadi bahan masukan kebijakan pemerintah kota Depok dalam menurunkan angka perceraian di kota Depok.

\section{METODE PENELITIAN}

Metode yang digunakan dalam penelitian ini menggunakan metode kualitatif dengan pendekatan fenomenologi. Pendekatan tersebut dianggap cocok untuk menjawab pertanyaan penelitian yang bersumber dari pengalamanpengalaman subjektif partisipan yang ditemui selama penelitian dan berusaha melakukan interpretasi tentang berbagai permasalahan 
(Moleong, 2012). Dalam penelitian fenomenologi, peneliti berusaha melakukan interpretasi terhadap pengalaman yang didapatkan dari para partisipan penelitian dengan cara memberikan makna atas sesuatu yang dialami oleh partisipan. Dengan kata lain berbagai tindakan maupun perkataan partisipan diinterpretasikan sebagai temuan penelitian. Dalam penelitian fenomenologi peneliti harus mengesampingkan subjektivitas, agar peneliti dapat memahami secara objektif sesuai dengan temuan subjek penelitian (Creswell, 2014). Fenomena perceraian akibat penyalahgunaan media sosial dianalisis bersumber dari informasi didapatkan oleh partisipan yang mengalami langsung perceraian karena adanya perselingkuhan di media sosial. Diharapkan dengan fenomena ini dapat menjadi bahan masukan bagi pengambil kebijakan dalam melakukan upaya pencegahan maraknya perceraian akibat penyalahgunaan media sosial.

Peneliti melakukan pengumpulan data berdasarkan hasil observasi, wawancara, dan studi dokumentasi. Pengolahan data menggunakan aplikasi Nvivo 12 Plus. Nvivo merupakan sebuah software yang bertujuan untuk melakukan koding terhadap sumber data penelitian secara efektif dan efisien (Bandur, 2019). Penggunaan NVivo memudahkan peneliti dalam melakukan visualisasi data penelitian tentang perceraian akibat penyalahgunaan media sosial sehingga lebih efektif dan efisien.

Penelitian dilakukan di Kota Depok Jawa Barat. Penelitian dilakukan dari bulan Maret sampai dengan bulan September 2020. Partisipan penelitian berjumlah 10 partsipan berupa: partisipan kunci berjumlah 7 masyarakat kota Depok yang bercerai akibat penyalahgunaan media sosial meliputi narasumber A, F, H, K, M, W dan Y. Partisipan pendukung berjumlah 3 orang yang memiliki keterkaitan terhadap masalah penelitian meliputi: partisipan Pengadilan Agama, Dinas Perlindungan Anak Pemberdayaan Masyarakat dan Keluarga, dan Unit Pelaksana Teknis Daerah Perlindungan Perempuan dan Anak.
Penelitian ini menggunakan analisis data kualitatif. Menurut Miles dan Huberman (Silalahi, 2010) analisis data kualitatif terdiri dari tiga proses yaitu: peneliti melakukan proses reduksi data, menyajikan data, dan menarik kesimpulan penelitian atau melakukan verifikasi. Setelah data dianalisis berdasarkan temuan penelitian yang diperkuat dengan teori dan penelitian relevan, kemudian didapatkan hasil penelitian yang dapat dijadikan sebagai temuan baru penelitian terkait dengan masalah upaya pencegahan perceraian akibat penyalahgunaan media sosial.

\section{HASIL DAN PEMBAHASAN}

Keluarga merupakan unit sosial terkecil dalam masyarakat sehingga keluarga menjadi pondasi utama dalam pembangunan kehidupan masyarakat. Jika banyak mengalami perceraian, bagaimana dapat mencetak generasi penerus bangsa yang berkualitas. Selain itu, dampak perceraian bukan hanya berdampak pada pasangan, tetapi juga berdampak pada anak yang menjadi korban dari perpisahan orangtuanya. Bahkan perceraian dapat menimbulkan permasalahan sosial baru di masyarakat. Oleh karena itu, besarnya dampak yang ditimbulkan, perlu adanya upaya yang dapat dilakukan untuk menekan perceraian baik dalam bentuk preventif maupun represif yang dapat dilakukan oleh pemerintah pusat, pemerintah daerah, sampai elemen masyarakat untuk menekan angka perceraian.

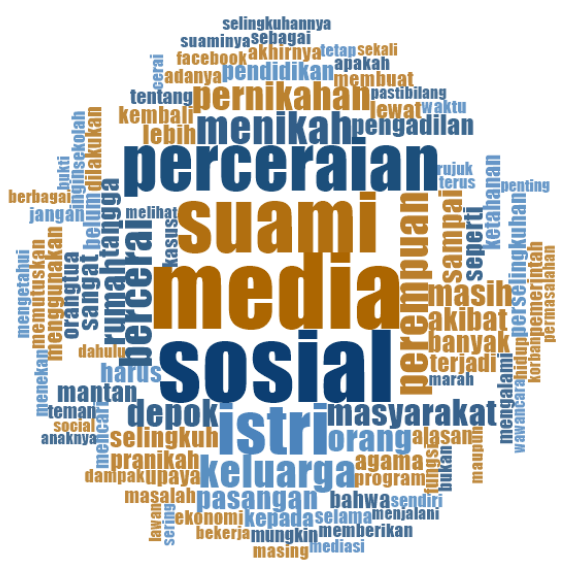

Gambar 1. Hasil Penelitian Word Frequency Sumber: (Data peneliti. 2020) 
Pada penelitian menggunakan pengolahan data NVivo 12 untuk mengecek apakah hasil analisis data sesuai dengan topik penelitian dengan menggunakan Word Frequency (Lihat gambar 1). Terkait dengan hasil Word Frequency menggunakan NVivo 12 Plus, menunjukkan bahwa kata "Media" merupakan kata yang paling banyak muncul sebanyak 266 kata, kata "social" terdapat 253 kata, "perceraian" terdapat 173 kata, kata "bercerai" sebanyak 129 kata, kata "upaya" terdapat 68 kata. Berdasarkan hasil Word Frequency dari data penelitian menunjukkan bahwa semua dokumen saling berkaitan sesuai dengan pembahasan penelitian terkait dengan perceraian akibat media sosial. Penelitian ini berupaya untuk menjelaskan berbagai upaya yang dapat dilakukan oleh berbagai pihak untuk menekan angka perceraian yang akan dijelaskan sebagai berikut.

\section{Upaya yang Dilakukan Pasangan}

Menjalani kehidupan rumah tangga tidak selalu sesuai dengan apa yang diharapkan. Ketika dua orang disatukan dengan ikatakan pernikahan kerap kali menimbulkan konflik antara pasangan suami istri. Kembali lagi pada esensi pernikahan yang tercantum dalam Undang-Undang Nomor 1 Tahun 1974 Pasal 1 menjelaskan bahwa "perkawinan adalah adanya ikatan lahir batin antara suami dan istri dengan tujuan membentuk keluarga bahagia berdasarkan Ketuhanan Yang Maha Esa" (Pemerintah Republik Indonesia, 1974). Berdasarkan undang-undang tersebut menekankan bahwa pernikahan sebagai perwujudan bentuk ketaatan manusia kepada Tuhan Yang Masa Esa, jika hal tersebut selalu dihadirkan dalam kehidupan rumah tangga maka apapun permasalahan yang terjadi dalam kehidupan rumah tangga dapat diselesaikan dengan baik karena pertanggungjawabannya dihadapan Tuhan.

Konflik dalam rumah tangga dapat terjadi banyak penyebabnya, salah satunya karena adanya orang ketiga yang hadir dalam hubungan suami isteri yang saat ini mudah terungkap lewat keberadaan media sosial. Penggunaan media sosial dapat berdampak positif maupun negatif tergantung penggunanya. Ketika suami atau isteri yang menggunakannya media sosial dengan positif maka dapat menjadi alat komunikasi efektif antara pasangan suami isteri. Sedangkan penggunaan media sosial secara negatif akan dapat mendatangkan malapetaka yang dapat menghancurkan rumah tangga dengan hadirnya orang ketiga.

Upaya yang dilakukan pasangan untuk mempertahankan keluarga dengan cara memaafkan kesalahan pasangan yang telah selingkuh lewat media sosial dan berusaha memberikan kesempatan kepada pasangan agar kembali bersama berumahtangga. Kepercayaan yang diberikan menjadi pondasi untuk mempertahankan hubungan keluarga dan tetap menjalin keharmonisan dalam rumah tangga. Namun ketika rasa kepercayaan kepada pasangan telah hilang karena pasangan tetap melakukan perselingkuhan lewat media sosial maka partisipan lebih memilih untuk tidak lagi mempertahankan hubungan rumah tangga sehingga perceraian menjadi solusi terbaik bagi pasangan. Sebagaimana yang diungkapkan oleh narasumber A:

"Saya telah berupaya memaafkan kesalahan istri yang telah berselingkuh dengan laki-laki yang dia kenal lewat instagram dan facebook. Namun, lama kelamaan saya capek dengan kelakuannya yang tidak berubah sampai akhirnya dia meninggalkan saya dan anak saya demi orang yang baru dikenal lewat media sosial" (Wawancara dengan Narasumber A, 31 Mei 2020).

Partisipan berusaha mempertahankan rumah tangga agar tidak bercerai terutama alasan yang paling mengemuka adalah demi menjaga masa depan anak. Oleh karena itu rumah tangga masih tetap dipertahankan meskipun secara hubungan rumah tangga sudah tidak harmonis lagi. Setelah partisipan memberikan kesempatan kepada pasangan untuk memperbaiki keadaan untuk tidak melakukan selingkuh di media sosial, namun menemukan perilaku yang sama sehingga partisipan memutuskan untuk bercerai. Perselingkuhan di media sosial yang dilakukan pasangan dapat 
menjadi alasan krusial bagi pasangan untuk tidak rujuk kembali.

Media sosial yang digunakan pasangan dalam melakukan perselingkuhan biasanya terdapat dalam platform seperti: Facebook dan Whats App. Awalnya dari kenalan di media sosial dengan lawan jenis atau hanya untuk menjalin komunikasi dengan mantan pasangan, berlanjut dengan saling mencurahkan isi hati terhadap berbagai persoalan sehingga melupakan keluarga, interaksi dalam dunia nyata berlajut kedunia nyata, dan akhirnya menghancurkan rumah tangga. Untuk meminimalisir terjadinya perpisahan, seyogyanya pasangan suami istri dapat saling menjaga kepercayaan satu sama lain. Keterbukaan atau kejujuran antar pasangan, dan berkomitmen terhadap perkawinan juga hal yang diperlukan. Oleh karena itu, perlu adanya upaya untuk dapat menyelesaikan masalah dengan baik, mengelola sebuah konflik dalam rumah tangga, sehingga ketika ada permasalahan maka pasangan suami isteri tidak cepat untuk memutuskan berpisah.

Salah satu temuan dalam penelitian ini menunjukkan bahwa kurangnya pengetahuan partisipan tentang pernikahan khususnya tentang resiko jika pasangan melakukan penyalahgunaan penggunaan dalam media sosial yang akan berdampak besar bagi pasangan. Pada saat terjadi konflik akibat perselingkuhan yang diketahui pasangan, maka dapat terjadi konflik antara suami dan isteri, bahkan sampai berujung pada tindakan kekerasan dalam rumah tangga, sebagaimana yang dialami oleh narasumber $\mathrm{K}$.

Oleh karena itu, dalam menghadapi permasalahan diperlukan manajerial konflik yang belum bisa diterapkan, khususnya pasangan yang menikah di usia muda sehingga sangat rentan terhadap konflik dalam rumah tangga karena emosi yang masih labil. (Lihat gambar 2)

Berdasarkan gambar tersebut jelas menunjukkan bahwa sebagian besar partisipan menikah dengan pada usia 16 sampai dengan 20 tahun. Dalam Undang-Undang Nomor 16 tahun 2019 pasal 7 tentang Perkawinan, dijelaskan bahwa usia menikah ketika laki-laki dan perempuan sudah mencapai usia 19 tahun (Pemerintah Republik Indonesia, 2019).

Partisipan Kunci:Usia Saat Menikah - Cases by Attribute Value

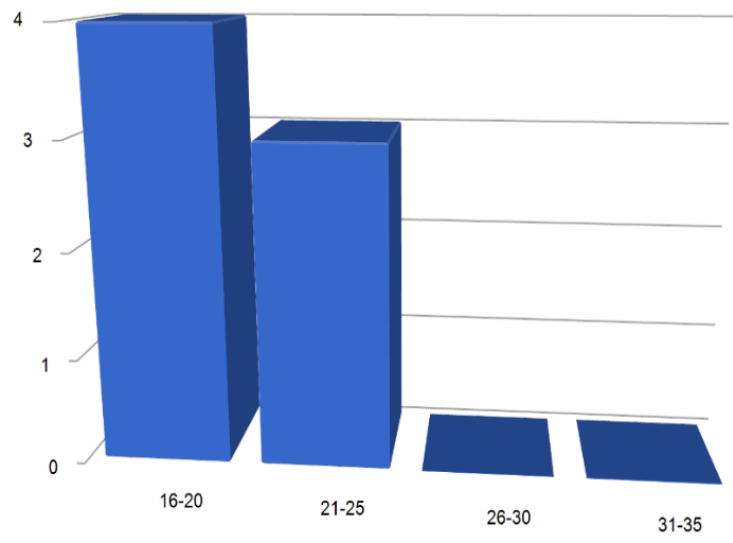

Gambar 2. Usia Partisipan Saat Menikah Sumber: (Data peneliti. 2020)

Pemerintah merekomendasikan usia ideal saat menikah yaitu laki-laki berusia 25 tahun, sedangkan perempuan berusia 21 tahun. Pada usia tersebut dianggap sudah dewasa secara fisik, mapan dalam hal finansial, dan sudah memiliki kematangan secara emosionalnya. Sebagaimana yang disampaikan oleh Pengadilan Agama:

"Usia masyarakat yang rentan bercerai usia 18-30 tahun dan rentang usia pernikahan 1-10 tahun". (Wawancara dengan Pengadilan Agama Depok, 7 Agustus 2020).

Upaya pencegahan perceraian yang dilakukan pasangan dimulai dari sebelum menikah dimana pasangan pengantin harus memiliki kesiapan jiwa raga dalam mengarungi bahtera rumah tangga, sehingga ketika menikah dapat menyelesaikan masalah dengan baik oleh kedua belah pihak, termasuk masalah yang akan terjadi apabila pasangan selingkuh lewat media sosial.

Kerap kali ditemukan pasangan yang melakukan perselingkuhan di media sosial akibat penyembunyian status yang dimiliki, ditambah dengan komunikasi intensif dengan lawan jenis atau dengan mantan kekasih sehingga menimbulkan perasaan sayang dan 
pada akhirnya memicu pertengakaran karena mucul perasaan jenuh dengan pasangan dalam rumah tangga. Oleh karena itu, hal-hal yang dapat mendatangkan permasalahan tersebut dapat diminimalisir akar permasalahannya dan dimusyawarakan dengan baik agar pasangan dapat mempertahankan rumah tangga.

\section{Upaya yang Dilakukan Orangtua}

Menikah bukan hanya menyatukan dua pasangan suami isteri tetapi juga menyatukan kedua keluarga. Ketika ada permasalahan di dalam rumah tangga konflik akibat penyalahgunaan media sosial, sehingga tidak menutup kemungkinan diketahui oleh keluarga kedua belah pihak. Upaya yang dilakukan keluarga atau orangtua untuk mendamaikan suami istri yang berkonflik, mencarikan solusi atas permasalahan yang mereka hadapi. Orangtua harus menjembatani agar anak tidak bercerai dan melakukan rujuk kembali. Selagi permasalahan yang dihadapi masih bisa ditolerir dan dimaafkan, sebagaimana yang telah dilakukan keluarga Narasumber W sebagai berikut:

"Orangtua pernah bilang kepada saya untuk rujuk saja demi anak, lagi pula orang tua menganggap perselingkuhan di media sosial tidak fatal masih bisa dimaafkan dan meminta saya rujuk kembali". (Wawancara dengan Narasumber W, 21 Juni 2020).

Berdasarkan hasil wawancara tersebut orangtua memberikan penguat untuk dapat mempertahankan rumah tangga demi masa depan anak-anak. Pada dasarnya orangtua menginginkan yang terbaik untuk anaknya, sehingga ketika sudah dilakukan musyawarah dengan keluarga untuk merekomendasikan anak kembali rujuk kembali dengan pasangan, namun jika hasil musyawarah mengalami kebuntuan ditambah dengan berbagai penderitaan lahir batin yang dirasakan secara terus menerus sehingga membuat orang tua mendukung apapun yang menjadi keputusan anaknya, termasuk untuk berpisah jika itu menjadi jalan yang terbaik dan banyak bahaya sekaligus dampak yang ditimbulkannya jika masih dipertahankan kehidupan rumah tangga.

\section{Upaya yang Dilakukan Masyarakat}

Permasalahan di dalam keluarga kerap kali membawa pengaruh terhadap kehidupan masyarakat. Oleh karena itu, upaya yang dilakukan dalam mencegah perceraian bukan hanya ditekankan kepada keluarga tetapi juga disebarluaskan kepada masyarakat. Penggunaan media social dapat memberikan dampak positif maupun negatif tergantung pada penggunanya yang dapat menentukan tujuan penggunaannya. Namun kiranya perlu adanya sosialisasi untuk meningkatkan pengetahuan bagi masyarakat tentang bermedia social yang bijak dengan menjalankan fungsinya dengan baik seperti media sosial sebagai sarana komunikasi antar masyarakat, media bisnis, media informasi tentang berbagai peristiwa yang terjadi, dan sebagainya. Sedangkan pengetahuan tentang dampak negatif dari penggunaan media social perlu diketahui masyarakat terutama bahaya media social dalam menghancurkan hubungan rumah tangga.

Upaya penguatan peran keluarga didalam kehidupan masyarakat dapat dilakukan oleh tokoh masyarakat, tokoh agama, tokoh akademisi dalam kegiatan pengabdian kepada masyarakat, melibatkan Rukun Warga (RW), Rukum Tetangga (RT), dan berbagai tokoh yang berperan dalam masyarakat dalam menciptakan rumah tangga yang harmonis sehingga berimbas pada kehidupan masyarakat aman dan damai. Upaya yang dilakukan dengan cara pemberian sosialisasi, pendampingan, penyuluhan, pembinaan, konsultasi tentang penguatan peran keluarga.

\section{Upaya yang Dilakukan Pemerintah}

Upaya yang dilakukan baik oleh pemerintah daerah maupun pemerintah pusat. Upaya pemerintah pusat untuk menekan angka perceraian dengan berbagai regulasi kebijakan. Melalui Undang-Undang Nomor 1 Tahun 1974 tentang Perkawinan, Peraturan Pemerintah Nomor 9 Tahun 1975, Undang-Undang Nomor 16 Tahun 2019 tentang Perubahan Atas UndangUndang Nomor 1 Tahun 1974 Tentang Perkawinan, dan berbagai regulasi lainnya untuk mengatur masalah perkawinan dan perceraian. Adapun Rancangan Undang-Undang Ketahanan 
Keluarga bertujuan untuk memperkuat ketahanan Bangsa dari berbagai ancaman termasuk maraknya perceraian (Nursyifa, 2020).

Perlu adanya kebijakan khusus untuk mengatur penggunaan media social misalnya dengan adanya pengetahuan kepada masyarakat tentang etika bermedia social bagi keluarga. Hal ini sangatlah penting dilakukan, karena kurangnya pengetahuan masyarakat tentang dampak buruk bermedia social dapat menimbulkan berbagai pelanggaran yang dapat terjadi, misalnya pelanggaran tentang UndangUndang Informasi dan Transaksi Elektronik (ITE). Ditambah lagi, perlu adanya kebijakan yang secara komprehensif mengatur perlindungan korban perceraian baik bagi perempuan maupun anak yang kerap kali menjadi objek kekerasan.

Regulasi ditingkat daerah dapat dilakukan dengan membuat kebijakan untuk menekan angka perceraian, sebagaimana yang dilakukan oleh pemerintah kota Depok dalam Peraturan Daerah Kota Depok Nomor 9 Pasal 14 Tahun 2017 Tentang Peningkatan Ketahanan Keluarga, bahwa:

"perlu adanya pembinaan suami isteri (1) bertujuan untuk mencegah terjadinya perceraian, ketidakharmonisan keluarga, dan kekerasan dalam rumah tangga. (2) Pembinaan dalam bentuk: a.seminar; $b$. lokakarya; c. konsultasi; d.promosi ketahanan keluarga"(Pemerintah Kota Depok, 2017). Lewat aturan tersebut menjadi dasar untuk melakukan berbagai program dalam memperkuat ketahanan keluarga di Kota Depok, sebagaimana yang diungkapkan oleh Dinas Perlindungan Anak Pemberdayaan Masyarakat dan Keluarga (DPA PMK) bahwa "kota Depok memiliki program unggulan: Depok yang berketahanan keluarga, maka sebagai upaya preventif perceraian dilakukan berbagai macam cara diantaranya lewat kegiatan penekanan pernikahan dini dengan mengadakan pendidikan pranikah dan sekolah ayah bunda"

(Wawancara dengan DPA PMK Kota Depok, 12 Agustus 2020).

Pernikahan dini membawa dampak yang besar bagi hubungan pernikahan terutama sangat rentan untuk bercerai, sebagaimana pengalaman partisipan yang menikah dini, sehingga muncul banyak permasalahan didalam rumah tangga akibat ketidaksiapan dalam pendewasaan diri sehingga mudah berkonflik karena saling mempertahankan ego masing-masing. Dilihat dari segi ekonomi, pasangan yang belum cukup usianya relatif belum mapan sehingga dalam pemenuhan kebutuhan rumah tangga, jika ada permasalahan dirumah tangga maka pelampiasan mencari kesenangan dilakukan lewat media sosial. Usia pernikahan yang sudah matang sebagaimana yang direkomendasikan pemerintah termasuk matang secara psikologi adalah bilamana perempuan berusia 21 tahun sedangkan laki-laki berusia 25 tahun. Dengan usia siap menikah diharapkan dapat menekan pernikahan dini dan dapat meminimalisir terjadinya perceraian.

Salah satu upaya menekan pernikahan usia dini, dengan melakukan sosialisasi kepada generasi muda dengan adanya pendidikan pranikah. Pendidikan pranikah merupakan sarana edukasi yang diberikan oleh pemerintah daerah kota Depok dalam memberikan solusi untuk menekan angka peceraian di kota Depok. Sebagaimana yang disampaikan oleh pegawai pada DPA PMK Kota Depok:

"program ini diberikan kepada remaja usia 20 tahun keatas dan belum pernah menikah. Sekolah pranikah digelar setiap tahunnya, pada tahun 2018 dengan peserta 40 peserta, tahun 2019 terdapat 5 angkatan yang berjumlah 250 peserta. Tahun 2020 terlaksana 2 angkatan yang berjumlah 100 peserta" (Wawancara dengan DPA PMK Kota Depok, pada 12 Agustus 2020).

Program Pendidikan pranikah sangat bermanfaat dan urgent bagi remaja untuk mempersiapkan diri menuju jenjang selanjutnya yaitu pernikahan. Didalamnya terdapat materi tentang Undang-Undang Perkawinan serta ketentuan peraturan perundang undangan lainnya; memperkuat fungsi keluarga sesuai norma agama, adat, sosial; kesehatan reproduksi; pendidikan dan pengasuhan anak; pendampingan ekomoni keluarga; membentuk keharmonisan keluarga; dan lain-lain. Gamabaran tentang kegiatan Pendidikan pranikah (Lihat gambar 3) 


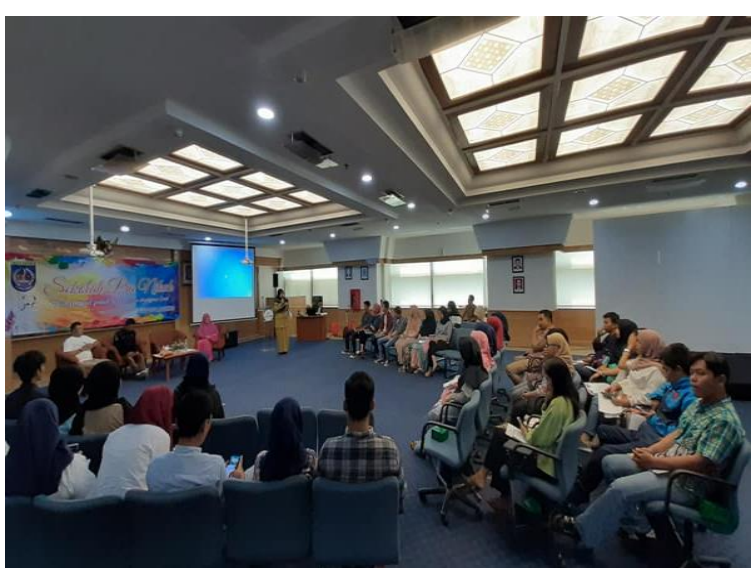

Gambar 3. Dokumentasi Pendidikan Pranikah Sumber: (DPA PMK Depok, 2019)

Jika pendidikan pranikah terus dijalankan maka besar harapan dapat menurunkan tingkat perceraian yang tinggi dikota Depok, karena generasi muda sudah mempersiapkan diri untuk menikah dan program ini dapat menjangkau seluruh generasi muda di kota Depok yang sudah siap menikah dan program ini dapat dilakukan secara berkelanjutan. Tidak seperti yang dialami para partisipan, mereka belum pernah mendapatkan pendidikan pranikah, Adapun edukasi tentang pernikahan hanya didapatkan di Kantor Urusan Agama (KUA) sewaktu ingin menikah, pada akhirnya minimnya pengetahuan tentang pernikahan membuat mereka sangat rentan untuk bercerai, salah satunya yang diakibatkan karena permasalahan penyalahgunaan media sosial. Oleh karena itu, perlu adanya program pendidikan pranikah yang dapat menjadi solusi pencegahan perceraian.

Selain adanya pendidikan pranikah, perlu juga dilakukan penguatan ketahanan keluarga untuk mencegah perceraian. Ketahanan keluarga menjadi faktor utama dalam penguatan keluarga, salah satunya dapat dilakukan dengan penguatan fungsi-fungsi keluarga. Berdasarkan Peraturan Pemerintah Republik Indonesia Nomor 87 Tahun 2014 pasal 7 ayat 1 dan 2, tentang Perkembangan Kependudukan dan Pembangunan Keluarga, Keluarga Berencana, dan Sistem Informasi Keluarga dijelaskan terdapat 8 fungsi keluarga yang harus dijalankan secara optimal (Pemerintah Republik Indonesia, 2014). (Lihat Gambar 4)

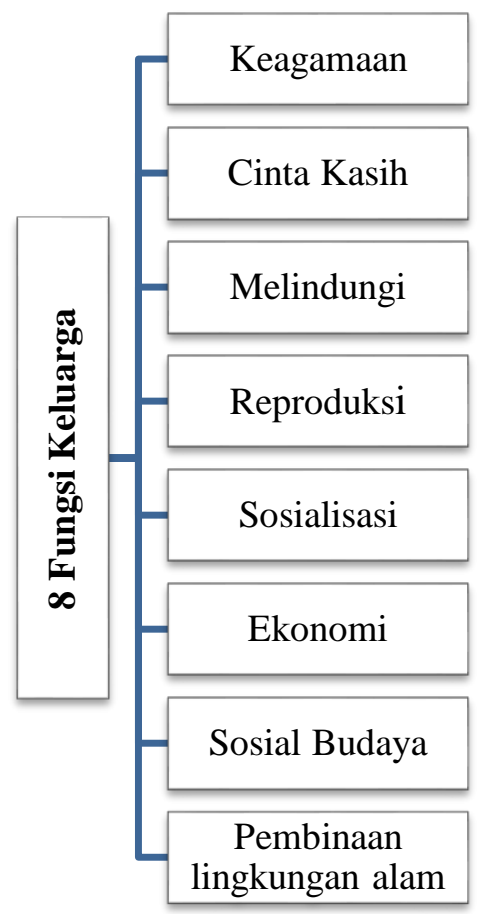

Gambar 4. Fungsi keluarga

Sumber: (Data peneliti, 2020)

Fungsi keluarga harus terimplementasi dengan baik dalam kehidupan keluarga. Jika salah satu fungsinya tidak berjalan dengan baik maka mengkhawatirkan adanya permasalahan dalam keluarga. Terutama adalah fungsi agama, jika agama menjadi pondasi dalam pernikahan maka niat menikah karena beribadah kepada Tuhan YME, nilai agama juga sangat penting dalam mengontrol pasangan dalam mencegah perselingkuhan lewat media sosial.

Pernikahan pasangan muda yang rentan bercerai karena hanya memenuhi satu fungsi keluarga saja dalam menikah, sebagaimana yang diungkap oleh pengadilan agama:

"Menikah bukan hanya memenuhi fungsi reproduksi saja, namun ada fungsi-fungsi lain yang harus dipenuhi suami isteri. Pasangan muda menikah karena factor cinta, tetapi nyatanya menjalani pernikahan tidak semudah apa yang dibayangkan ada banyak masalah yang harus dihadapi pada akhirnya cepat memutuskan bercerai. (Wawancara dengan Pengadilan Agama Depok, 7 Agustus 2020). 
Oleh karena itu, penguatan fungsi keluarga harus dikenalkan sejak dini kepada generasi muda melalui pendidikan pranikah. Pendidikan pranikah ini penting dilakukan karena setelah menikah pengetahuan tentang fungsi keluarga juga harus diberikan kepada pasangan suami istri sebagai upaya untuk mencegah perceraian, salah satunya lewat program sekolah ayah bunda.

"Sekolah ayah bunda pada tahun 2020 sudah 2 angkatan yang berjumlah 100 peserta, satu angkatan terdiri dari 25 pasang ayah bunda atau 50 peserta" (Wawancara dengan DPA PMK Kota Depok, 12 Agustus 2020).

Program sekolah ayah bunda berisi tentang materi esensi dari perkawinan dengan mengedepankan nilai-nilai dalam perkawinan dan keluarga, pentingnya menjalin hubungan harmonis sesuai norma agama, sosial, dan budaya, kerjasama anggota keluarga dalam suka duka, pengelolaan sikap dan emosional sebagai orang tua, pengembangan potensi dan karakter anak, bahaya dan dampak perceraian terhadap psikologis anak, hak dan kewajiban berdasarkan peraturan perundang-undangan yang berlaku. (Lihat gambar 5)

Program pendidikan pranikah dan sekolah ayah bunda merupakan dua program unggulan kota Depok dalam upaya mencegah tingginya tingkat perceraian. Kedua program tersebut dapat disisipi materi tentang kode etik bermedia sosial bagi pasangan suami istri, dan berbagai dampak yang dapat ditimbulkan akibat penyalahgunaan media sosial. Kedua program tersebut diharapkan dapat menjangkau seluruh lapisan masyarakat kota Depok dan harapannya dapat dilakukan secara berkelanjutan sehingga manfaat dari program tersebut dapat menjadi solusi masalah fenomena dari maraknya perceraian di kota Depok khususnya akibat penyalahgunaan media sosial.

Perceraian akibat penyalahgunaan media sosial kerapkali mendatangkan korban. Terdapat institusi yang melakukan perlindungan terhadap korban perceraian di kota Depok yaitu Unit Pelaksana Teknis Daerah Perlindungan Perempuan dan Anak (UPTD PPA) Depok.

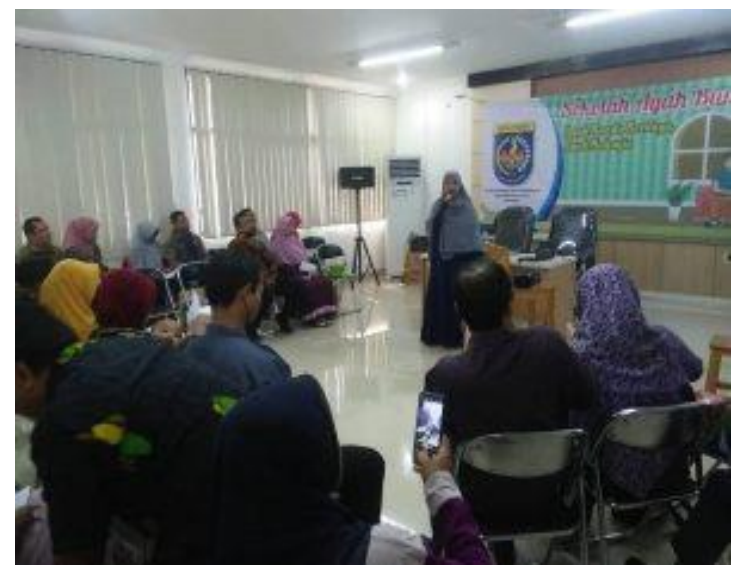

Gambar 5. Dokumentasi Sekolah Ayah Bunda Sumber: (Ardianto, 2018)

PPA berfungsi untuk melakukan pendampingan kepada perempuan dan anak yang menjadi korban perceraian yang sangat berdampak pada kondisi psikologis korban, melakukan pendampingan bagi korban di pengadilan, melakukan pendampingan korban di kepolisian jika terkait dengan masalah KDRT sampai dengan bantuan hukum, serta memberikan pelatihan bagi perempuan korban perceraian dengan keterampilan berwirausaha dan memberikan modal agar perempuan dapat memiliki kemandirian pasca bercerai dengan suami, mendampingi secara psikologis anak korban perceraian, melindungi anak korban perceraian, dan berupaya menghilangkan trauma anak dari perceraian orangtuanya. Jika terjadi permasalahan suami istri enggan berkonsultasi kepada pihak-pihak yang berwenang menganai masalah keluarga tersebut, sayangnya masyarakat belum sepenuhnya teredukasi dengan keberadaan lembaga tersebut. Bagaikan sebuah snowball masalah yang dihadapi berlarut-larut dan pada akhirnya akumulasi dari berbagai persoalan yang dihadapi dalam rumah tangga jika tidak tertangani dengan baik mengakibatkan permasalahan perceraian dalam rumah tangga, ketidakharmonisan didalam keluarga, dan kekerasan dalam rumah tangga. Oleh karena itu, pendampingan PPA kepada masyarakat sangat penting dalam menangani masalah perceraian akibat penyalahgunaan media sosial. Sebagaimana yang diungkapkan dengan wawancara PPA Depok berikut ini 
"Ketika ada perselingkuhan media sosial, maka kita upayakan untuk mediasi antara suami istri agar tetap mempertahankan rumah tangga. Kita tidak akan memberi rekomendasi untuk bercerai tetapi justru menghindari perceraian itu terjadi, karena kita menginginkan untuk keutuhan rumah tangga". (Wawancara dengan PPA Kota Depok, 10 September 2020).

Lembaga lainnya yang berperan dalam pencegahan perceraian yaitu pengadilan agama. Pengadilan agama memiliki peranan penting dalam upaya untuk mencegah perceraian. Suami isteri yang mengajukancerai di pengadilan agama tidak semua dikabulkan. Hakim akan mencari tahu permasalahan yang terjadi dalam rumah tangga termasuk masalah perceraian akibat penyalahgunaan media social. Media social pada dasarnya sebagai alat yang dapat merekam perbuatan perselingkuhan yang dilakukan pasangan. Sebagaimana yang diungkapkan oleh pengadilan agama, sebagai berikut.

Penyebab perceraian terdapat dalam undangundang perkawinan, penyebab perceraian akibat media social memang tidak muncul dalam aturan tetapi jika ditelusuri oleh hakim secara lebih mendalam maka akan menemukan permasalahan pertengkaran penyebabnya akibat perselingkuhan di media social (Wawancara dengan Pengadilan Agama Depok, 7 Agustus 2020).

Pengadilan agama berupaya agar dapat mendamaikan kedua belah pihak yang berkonflik karena perselingkuhan di media sosial. Mediasi dapat dilakukan dengan menghadirkan mediator dari luar atau non hakim, dan hakim yang diangkat menjadi mediator untuk mendamaikan kembali pasangan suami istri yang ingin bercerai agar rujuk kembali, prinsip dari hakim yaitu mempersulit terjadinya perceraian.

Pembahasan sosiologi mengenai upaya pencegahan perceraian akibat penyalahgunaan media sosial dianalisis menggunakan teori struktur fungsional yang memandang bahwa perlu adanya keteraturan dalam kehidupan baik anggota keluarga maupun masyarakat untuk berusaha mengabaikan konflik. Dalam teori struktur fungsional mengutamakan kehidupan keluarga yang harmonis dan meminimalisir terjadinya konflik dalam rumah tangga. Keluarga yang terdiri dari ayah, ibu, dan anak saling menjalani fungsinya masing-masing dalam rumah tangga. Ketika fungsi-fungsi keluarga tersebut tidak berjalan sebagaimana mestinya maka akan menimbulkan gejala disfungsi keluarga yang berujung pada perceraian. Menurut Merton institusi sosial dapat menyumbang keadaan positif maupun negatif terhadap sebuah sistem sosial, keadaan negatif inilah yang menyebabkan terjadi disfungsi sosial (Ritzer \& Goodman, 2010). Untuk meminimalisir keadaan disfungsional dalam keluarga dapat dilakukan upaya yang dimulai dari anggota keluarga, masyarakat, pemerintah kota, maupun pemerintah pusat. (Lihat gambar 6)

Mind map hasil penelitian tentang upaya pencegahan perceraian akibat penyalahgunaan media social divisualisasikan dengan menggunakan Nvivo 12 Plus. Sebagaimana yang telah diungkapkan dari pembahasan penelitian sebelumnya. Maka upaya pencegahan perceraian dapat dilakukan pasangan suami istri, mediasi yang dilakukan orangtua, masyarakat, serta upaya yang dilakukan oleh pemerintah daerah maupun pusat lewat berbagai program ketahanan keluarga.

Keluarga yang ideal menurut pandangan teori struktur fungsional dapat menjalankan fungsi keluarga dengan baik. Fungsi-fungsi keluarga yaitu : fungsi turunan, fungsi ekonomi, fungsi pendidikan atau sosialisasi, fungsi penentuan status, fungsi proteksi, fungsi pemeliharaan, dan fungsi afeksi atau perlindungan kepada setiap anggota keluarga (Narwoko \& Suyanto, 2014). Bilamana satu fungsi tidak berjalan maka, disfungsi menjadi keniscayaan. Hal ini selaras dengan 8 fungsi keluarga yang terdapat dalam Peraturan Pemerintah Kota Depok Nomor 9 Tahun 2007 Pasal 4 Ayat 2 Tentang Peningkatan Ketahanan Keluarga: "Peningkatan Ketahanan Keluarga Kota Depok bertujuan untuk mengoptimalkan fungsi keluarga dalam memenuhi kebutuhan fisik material dan mental spiritual secara seimbang" (Pemerintah Kota Depok, 2017). 


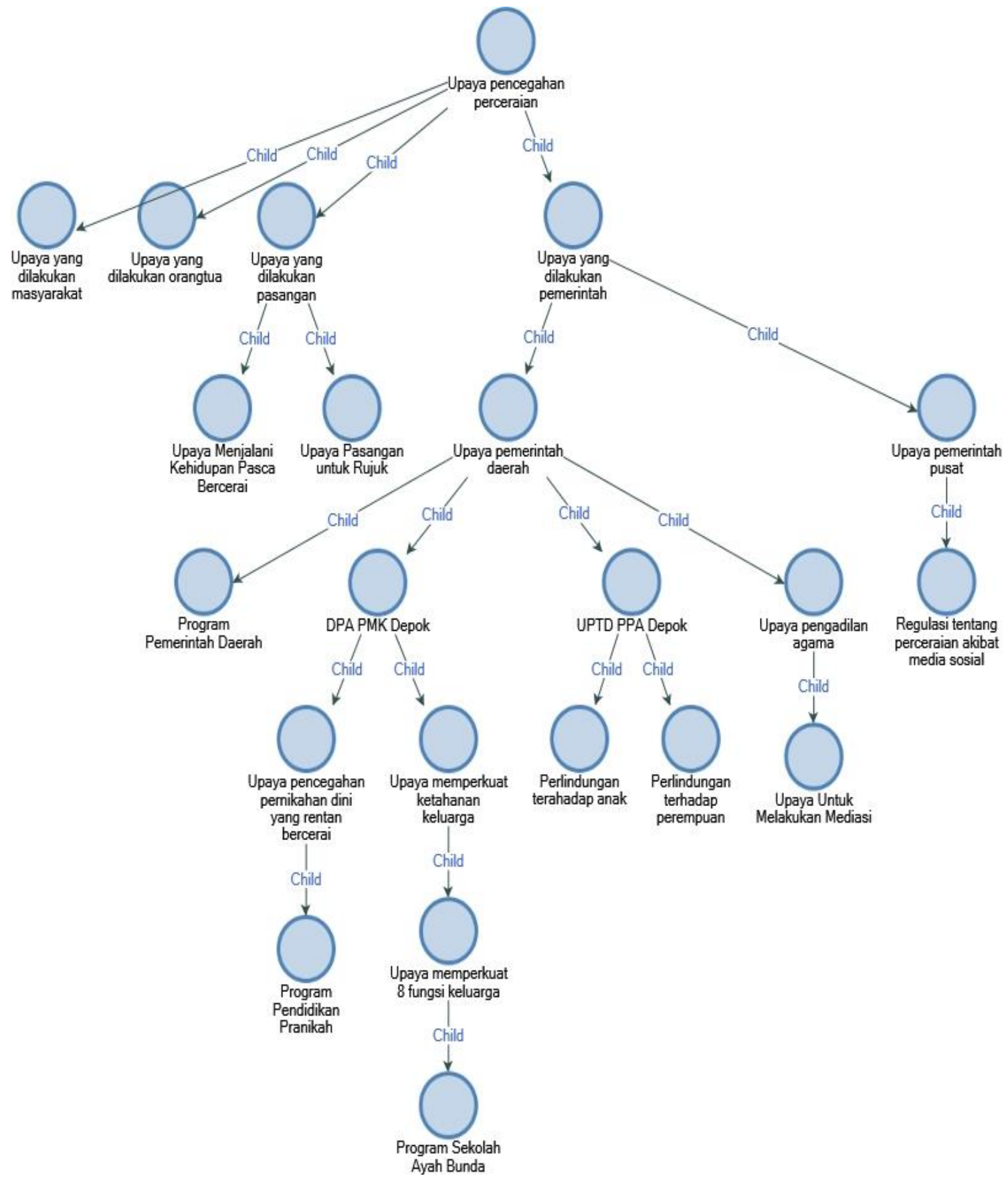

Gambar 6. Hasil Mind Map Penelitian Menggunakan Nvivo 12 Plus

Sumber: (Data peneliti, 2020)

Delapan fungsi yang dimaksudkan yaitu fungsi agama, cinta kasih, reproduksi, melindungi, sosialisasi dan pendidikan, ekonomi, social budaya, dan lingkungan hidup. Ketika 8 fungsi ini dijalankan maka akan meminimalisir terjadinya perceraian dalam rumah tangga terutama jika dikarena persoalan perselingkuhan lewat media social maka dapat diatasi dengan baik.
Memecahkan masalah perceraian dapat dilakukan berbagai lintas sektoral bukan hanya menjadi urusan dari lembaga pengadilan agama atau institusi perlindungan perempuan dan anak. Tetapi dapat dilakukan oleh berbagai institusi baik pemerintah pusat maupun daerah bersama dalam memberikan solusi untuk menekan kasus perceraian. Faktor yang menjadi penyebab perceraian dapat dianalisis baik melalui 
pengamat sosial maupun akademisi sehingga dapat dijadikan bahan pengambil kebijakan pemerintah kota agar angka perceraian bisa menurun. Oleh karena itu dibutuhkan kerjasama peran keluarga, anggota masyarakat, tokoh masyarakat, akademisi, psikolog, lembaga hukum, pengamat sosial, Pengadilan Agama, Dinas Perlindungan Anak Pemberdayaan Masyarakat dan Keluarga, dan Unit Pelaksana Teknis Daerah Perlindungan Perempuan dan Anak, dan berbagai lembaga lainnya secara terintegrasi dan berkelanjutan dalam memberikan sosialisasi, pendampingan, edukasi, pembinaan kepada keluarga sehingga dapat menekan angka percerain dan dapat mewujudkan keluarga yang sejahtera, keluarga yang bahagia baik lahir maupun batin. Oleh karena itu, diperlukan keberfungsian peranperan tidak hanya dalam keluarga tetapi fungsi dari berbagai tokoh maupun lembaga tersebut.

Penelitian tentang upaya untuk meminimalisir terjadinya perceraian akibat media sosial dilakukan dengan berbagai cara diantaranya: (1) adanya sekolah pranikah untuk memberikan edukasi kepada masyarakat sebelum melangsungkan pernikahan agar dapat mengatasi konflik dan terhindar dari perceraian (Hakim, 2016), (2) perselingkuhan dalam rumah tangga dapat dicegah dengan membangun komitmen sejak awal agar terhindar dari perceraian (Prianto, Wulandari, \& Rahmawati, 2013), komitmen dibangun sejak awal pernikahan untuk setia terhadap pasangan; (3) melakukan pembinaan bagi suami dan istri dengan cara seminar, lokakarya, konsultasi dan promosi ketahanan keluarga (Pemerintah Kota Depok, 2017). Manfaat dari hasil penelitian ini dapat menjadikan bahan kajian lebih lanjut mengenai upaya pencegahan perceraian akibat penyalahgunaan media sosial sehingga dapat ditindak lanjuti untuk para pengambil kebijakan untuk menekan angka perceraian.

Implikasi dari hasil penelitian ini menjadi memberikan kesadaran bagi masyarakat untuk dapat menggunakan teknologi secara bijak sehingga dapat meminimalisir terjadinya perceraian akibat media sosial. Memberikan edukasi kepada masyarakat untuk dapat membentuk ketahanan keluarga sehingga terhindar dari masalah perceraian.

\section{PENUTUP}

Upaya yang dilakukan dalam mencegah perceraian akibat penyalahgunaan media sosial dapat dilakukan dari sebelum melangsungkan pernikahan sampai pada setelah menikah. Program-program yang telah dijalani sebagai upaya pencegahan perceraian seperti pendidikan pranikah, sekolah ayah bunda, pendampingan terhadap perempuan dan anak sebagai korban perceraian, dan program lain untuk memperkuat ketahanan keluarga dioptimalisasikan dan dilakukan secara berkelanjutan sehingga dapat menjangkau seluruh lapisan masyarakat.

Oleh karena itu, upaya dapat ditempuh dengan adanya kerjasama semua pihak dan lintas sektor mulai dari keluarga, masyarakat, pengadilan agama, Dinas Perlindungan Anak Pemberdayaan Masyarakat dan Keluarga, dan Unit Pelaksana Teknis Daerah Perlindungan Perempuan dan Anak, dan berbagai lembaga lainnya untuk menjadikan keluarga yang harmonis, keluarga yang sejahtera, serta keluarga yang bahagia lahir batin. Keluarga yang ketahanan keluarganya baik maka akan berpengaruh pada ketahanan Bangsa Indonesia.

Selain itu, penelitian ini diharapkan menjadi bahan kebijakan pemerintahan khususnya kota Depok sehingga dapat mengambil keputusan untuk menekan angka perceraian di kota Depok.

\section{DAFTAR RUJUKAN}

Ardianto, W. Ek. (2018). Media Sosial Sebagai Penyebab Permasalahan Rumah Tangga Dalam Perspektif Hukum Islam. Institut Agama Islam Negeri Tulunganggung.

Asmaret, D. (2018). Perceraian Melalui Media Sosial. Menara Ilmu, 12(6). https://doi.org/10.1063/1.4914609

Astuti, Y. (2012). Facebook sebagai pemicu perselingkuhan yang berdampak pada perceraian. Universitas Islam Negeri Syarif Hidayatullah Jakarta.

Bandur, A. (2019). Penelitian Kualitatif Studi 
Multi Disiplin Keilmuan dengan NVivo 12 Plus. Jakarta: Mitra Wacana Media.

Baso, M. (2012). Dampak Teknologi Informasi dan Komunikasi Terhadap Peningkatan Jumlah Kasus Perceraian. UIN Alaudin Makassar.

Cahyono, A. S. (2010). Pengaruh Media Sosial Terhadap Perubahan Sosial Masyarakat Indonesia. Jurnal Publiciana, 9(1), 140-157.

Creswell, H. W. (2014). Research Design Pendekatan Kualitatif, Kuantitatif, dan Mixed. Yogyakarta: Pustaka Pelajar.

DPA PMK Depok. (2019). Dokumentasi Kegiatan Pranikah.

Hajar, S. (2019). Gugatan Perceraian Dikarenakan Perselingkuhan di Media Sosial Menurut Hukum Islam. Universitas Sumatera Utara.

Hakim, M. S. (2016). Sekolah Pranikah Lembaga Keagamaan Islam dan Prospek Penekanan Tingkat Perceraian Di Kota Yoyakarta (UIN Sunan Kalijaga Yogyakarta). Retrieved from http://digilib.uinsuka.ac.id/23116/2/1420310013

Harlina, Y. (2015). Dampak Komunikasi Jejaring Sosial terhadap Kehidupan Perkawinan dalam Islam. Hukum Islam, 15(1), 83-108. https://doi.org/10.24014/hi.v15i1.1158

Hootsuite. (2019). Digital 2019 Indonesia. Retrieved from https://datareportal.com/reports/digital -2019-indonesia

mahkamahagung.go.id. (2019). Keadaan Perkara Tingkat Pertama tahun 2019. Retrieved January 2, 2020, from https://badilag.mahkamahagung.go.id/

Moleong, L. J. (2012). Metode Penelitian Kualitatif. Bandung: Rosdakarya.

Narwoko, J. D., \& Suyanto, B. (2014). Sosiologi Teks Pengantar dan Terapan. Jakarta: Kencana.

Noor, S. A., Djaba, T., \& Enomoto, C. E.
(2016). The Role of Social Networking Websites: Do They Connect People Through Marriage or Are They Responsible for Divorce. Journal Of International Social Issues, 4(1), 40-49. Retrieved from https://www.winona.edu/socialwork/m edia/noor

Nursyifa, A. (2020). Rancangan UndangUndang Ketahanan Keluarga Dalam Perspektif Sosiologi Gender. Jurnal Pendidikan Kewarganegaraan, 7(1), 55-68. Retrieved from http://www.openjournal.unpam.ac.id/i ndex.php/PKn/article/view/6610/pdf

Pemerintah Kota Depok. Peraturan Daerah Kota Depok Nomor 9 Tahun 2017 Tentang Peningkatan Ketahanan Keluarga. , (2017).

Pemerintah Republik Indonesia. Undangundang Republik Indonesia Nomor 1 Tahun 1974 Tentang Perkawinan. , (1974).

Pemerintah Republik Indonesia. Peraturan Pemerintah Republik Indonesia Nomor 87 Tahun $2014 \quad$ Tentang Perkembangan Kependudukan dan Pembangunan Keluarga Berencana, dan Sistem Informasi Keluarga. , (2014).

Pemerintah Republik Indonesia. UndangUndang Nomor 16 Tahun 2019 tentang Perubahan Atas UndangUndang Nomor 1 Tahun 1974 Tentang Perkawinan. , (2019).

Pengadilan Agama Depok. (2019). Laporan Pelaksanaan Kegiatan Pengadilan Agama Depok 2019. Retrieved from http://www.pa-depok.go.id

Prianto, B., Wulandari, N. W., \& Rahmawati, A. (2013). Rendahnya Komitmen Dalam Perkawinan Sebagai Sebab Perceraian. Jurnal Komunitas, 5(62), 208-218.

Ramulyo, M. I. (2014). Hukum Perkawinan Islam Suatu Analisis Dari undangUndang Nomor 1 Tahun 1974 dan Kompilasi Hukum Islam. Jakarta: 
Bumi Aksara.

Ritzer, G., \& Goodman, D. J. (2010). Teori Sosiologi Modern. Jakarta: Kencana.

Safria, R. (2014). Perselingkuhan Melalui Facebook dan SMS Penyebab Perceraian.

Schwab, K. (2016). The Fourth Industrial Revolution. Switzerland.

Silalahi, U. (2010). Metode Penelitian Sosial. Bandung: Aditama.

Ulfa, M. (2019). Analisis hukum islam terhadap penggunaan media sosial sebagai penyebab perceraian (UIN Alauddin Makassar).http://repositori.uinalauddin.ac.id/14644/1
Valenzuela, S., Halpern, D., \& Katz, J. E. (2014). Social network sites, marriage well-being and divorce: Survey and state-level evidence from the United States. Computers in Human Behavior, 36 ,

94-101.

https://doi.org/10.1016/j.chb.2014.03.0 34

Viva.co.id. (2019). Gara-gara Medsos, Banyak Wanita di Depok Pilih Menjadi Janda. Retrieved from https://www.viva.co.id/berita/metro/11 67513

Watie, E. D. S. (2011). Komunikasi dan Media Sosial (C ommunications and Social Media). The Messenger, 3(1), 69-75. https://doi.org/10.26623/themessenger. v3i2.270 